\title{
The effect of powdered spices formula on antioxidant activity and sensory quality of solid brem
}

\author{
Maramy, N.V., *Handayani, B.R. and Zaini, M.A. \\ Faculty of Food Technology and Agroindustry-University of Mataram, Indonesia
}

\begin{abstract}
Article history:
Received: 7 December 2020

Received in revised form: 19 July 2021

Accepted: 19 September 2021

Available Online: 26

September 2021
\end{abstract}

\section{Keywords:}

Sensory,

Tape,

Rice,

Phenolic

DOI:

https://doi.org/10.26656/fr.2017.5(S2).003

\begin{abstract}
Solid brem is one of Indonesian traditional food. The low level of antioxidant content might be increased by adding powdered spice formula which is rich in phenolic compounds. The objective of this study was to determine the effect of powdered spices formula on antioxidant activity and sensory quality of solid brem. The formulation of powdered spices was ginger, turmeric, cloves, nutmeg, pepper, and cinnamon in a ratio of 3: 1: 1: 1: 1: 0.5. Randomized Complete Block Design (RCBD) with six treatments of adding powdered spices formula $(0,1,2,3,4$, and $5 \%)$ and three replications were used as the method. The data were analyzed by analysis of variance (ANOVA) at a 5\% significance level using Co-Stat software and tested further by Orthogonal Polynomial Method (OPM) or using Honestly Significant Difference (HSD). The result showed that adding powdered spices formula on solid brem had a significant different effect on antioxidant activity, water activity, $\mathrm{pH}$ value, physical quality (texture and color), and sensory quality (hedonic) on color, taste, texture, and melting in the mouth. The addition of $4 \%$ of the spices formula is recommended to produce the best quality of solid brem with the following characteristic: $80.51 \%$ of antioxidant activity, $15.71 \mathrm{mg}$ GAE/g of material total phenol, $40.90 \%$ Brix of total dissolved solids, 0.55 water activity (Aw), 3.44 $\mathrm{pH}$ value, $9.08 \mathrm{~N}$ texture value (physical), and $84.68{ }^{\circ}$ Hue color value (physical). The product had light yellow; slightly spicy, solid and rather smooth texture, and melting in the mouth. The high content of antioxidant activity in the product proved the potential of using powdered spices in improving the antioxidant activity of solid brem.
\end{abstract}

\section{Introduction}

Antioxidants are compounds that play an important role in maintaining the health of the human body. Antioxidants can be both synthetic and natural. Septiana et al. (2017) and Wijewardhana et al. (2019) explained that spices contain natural antioxidants which rich in phenolic compounds. Traditional drinks with added various types of spices such as ginger, cardamom, lemongrass, and cloves showed greater phenolic levels and free radical scavenging capacities compare to traditional drinks without added spices. Regarding Edam et al. (2016) and Sayuti et al. (2018), the addition of cloves and nutmeg filtrate in powder drinks resulted in the highest antioxidant activity, which was $92.23 \mu \mathrm{g} / \mathrm{mL}$. Adding formulas for various types of spices will result in higher antioxidant activity than adding just one type of spice. It is supported by Listiana and Herlina (2015). Many regions have their own traditional food. Bima West Nusa Tenggara has a food named Minasarua which contain spices including ginger, turmeric, pepper, cloves, nutmeg, and cinnamon with a ratio $3: 1: 1: 1: 1: 0.5$ (Yasin, 2013). The formulation of various types of spices is indicated to be an opportunity to increase the functional properties of other food products that do not have antioxidant functional properties. One of the food products with minimal functional properties is solid brem.

Solid brem is one of the traditional foods resulting from the concentration and drying of glutinous rice fermented (GRF) or tape (in local term) liquid which has a solid form, a slightly sour-sweet taste, yellowish-white to brownish color, and contains sugar and starch dissolved in water. The optimal condition of producing brem in good quality was by fermenting the glutinous rice in 5 days (Hiovenaguna and Widjanarko, 2017). Moreover, adding $0.6 \%$ maltodextrin in the formulation of brem can optimize the yield by $35.93 \%$ and sugar total 81.51\% (Afandy and Widjanarko, 2018). Research 
related to the additional ingredients on improving the functional properties of solid brem, especially the antioxidant activity of solid brem has never been done (very limited). Spice formula can be chosen to improve the functional effect of solid brem due to its phenolics compound. Therefore, research on adding powdered spice formulas is needed to produce solid brem with high content of antioxidants and sensory properties favored by consumers.

\section{Materials and methods}

\subsection{Materials}

The materials used were glutinous white rice, yeast, water, fresh spices (ginger and turmeric), dried spices (cloves, nutmeg, pepper, and cinnamon), and chemicals, namely gallic acid brand Sigma Aldrich, DPPH compound brand Sigma Aldrich, methanol brand Merck, Folin-Ciocalteu reagent brand Merck, $\mathrm{Na}_{2} \mathrm{CO}_{3}$ solution brand Merck, and distilled water.

\subsection{Preparation of powdered spices}

The processing of powdered spices consisted of cleaning, drying, milling, weighing, and sieving steps (Rahmadani et al., 2015). Ginger and turmeric go through the washing and slicing stages before drying. The six types of spices were sun-dried for $12 \mathrm{hrs}$ at $33^{\circ} \mathrm{C}$, then milled and sieved with 80 mesh sieves. The spices formulations used were ginger, turmeric, cloves, nutmeg, pepper, and cinnamon with a ratio of $3: 1: 1: 1: 1: 0.5$ (Yasin, 2013). The powdered spices formula is ready to use directly.

\subsection{Processing of glutinous rice fermented liquid}

Processing of gllutinous rice fermented (GRF) liquid extract began with the process of cleaning $1 \mathrm{~kg}$ of white glutinous rice, followed by soaking for $3 \mathrm{hrs}$ in water at room temperature and followed by steaming for 30 mins at $100^{\circ} \mathrm{C}$. Then, the glutinous rice was cooled at room temperature, added with 4 grams of yeast, and fermented for 5 days in

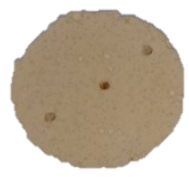

$(0 \%)$

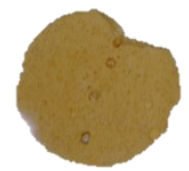

$(3 \%)$

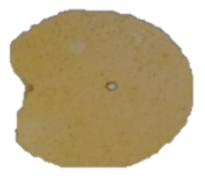

$(1 \%)$

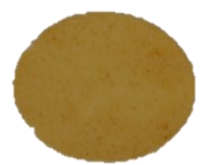

$(4 \%)$

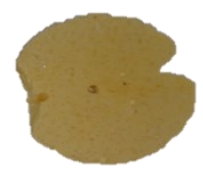

$(2 \%)$

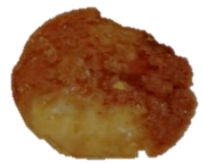

$(5 \%)$
Figure 1. Solid brem products with various treatment for addition of powdered spice formula

aerobic condition at room temperature (Hiovenaguna and Widjanarko, 2017) to produce fermented white sticky rice. The GRF was pressed using a manual pressing device to get the juice.

\subsection{Solid brem processing}

Glutinous rice fermented liquid was cooked for 10 mins $\left(80^{\circ} \mathrm{C}\right)$ to obtain a thick solution, then mixed with the powdered spice formula according to the treatment $(0,1,2,3$, 4 , and $5 \%$ of the weight of the solid brem dough). After that, it was re-cooked for 5 mins. The dough was stirred for 8 mins using a mixer until it is bubbly and kneading for 7 mins. The dough was weighed $25 \mathrm{~g}$ and molded in an aluminum foil-lined bowl. The final step was to allow the brem dough to become solid (Figure 1) for $96 \mathrm{hrs}$ at room temperature.

\subsection{Testing parameters}

The parameter testing in this research are water activity using a hygrometer (Public Health England, 2020), total dissolved solids using a hand refractometer (Ismawati et al., 2016), $\mathrm{pH}$ value using $\mathrm{pH}$ meter (Anisa et al., 2017), total phenolic using Folin Ciocalteu method (Khan et al., 2018), antioxidant activity using DPPH method, color physical test using colorimeter 
Table 1 . The chemical quality of solid brem with powder spice formula

\begin{tabular}{cccccc}
\hline $\begin{array}{c}\text { Concentration of } \\
\text { powdered spice } \\
\text { formula (\%) }\end{array}$ & Aw value & $\begin{array}{c}\text { Total dissolved } \\
\text { solids (\%Brix) }\end{array}$ & $\mathrm{pH}$ value & $\begin{array}{c}\text { Total phenolic value } \\
\text { (mg GAE/g material) }\end{array}$ & $\begin{array}{c}\text { Antioxidant } \\
\text { activity }\end{array}$ \\
\cline { 2 - 6 } 0 & $0.59^{\mathrm{a}}$ & 38.53 & $3.17^{\mathrm{b}}$ & 13.29 & $62.56^{\mathrm{b}}$ \\
1 & $0.56^{\mathrm{ab}}$ & 39.57 & $3.33^{\mathrm{ab}}$ & 12.42 & $71.28^{\mathrm{ab}}$ \\
2 & $0.55^{\mathrm{b}}$ & 40.73 & $3.32^{\mathrm{ab}}$ & 12.17 & $75.90^{\mathrm{ab}}$ \\
3 & $0.56^{\mathrm{ab}}$ & 40.83 & $3.40^{\mathrm{ab}}$ & 13.94 & $76.41^{\mathrm{ab}}$ \\
4 & $0.55^{\mathrm{b}}$ & 40.9 & $3.44^{\mathrm{ab}}$ & 15.71 & $80.51^{\mathrm{a}}$ \\
5 & $0.55^{\mathrm{b}}$ & 43.87 & $3.48^{\mathrm{a}}$ & 16.41 & $80.51^{\mathrm{a}}$ \\
HSD & 0 & - & 0.01 & - & 27.43 \\
\hline
\end{tabular}

HSD: Honestly Significance Difference. Values presented are mean. Values with the same superscripts within the same column are not significantly different at $\mathrm{p} \geq 0.05$.

(Hutching, 1999), texture using pnetrometer (Permata et al., 2015), sensory test (scoring and hedonic) with attributes of color, texture, aroma, and taste.

\subsection{Statistical analysis}

The method used was a single factor randomized block design with the addition of the concentration of powdered spices formula of $0,1,2,3,4$, and 5\%, 3 repetitions, and 18 experimental units. Data from parameter observation were analyzed by using ANOVA and considered significant if $\mathrm{p} \leq 0.05$ using Co-stat software. Significantly different data were further tested with the Orthogonal Polynomial test and Honestly Significant Difference (HSD) Test.

\section{Results and discussion}

\subsection{Chemical characteristic of solid brem}

The results of the chemical quality test (water activity, total dissolved solids, total phenolic, and antioxidant activity are listed in Table 1 . The addition of powdered spices affected the value of water activity (Aw), acidity, and antioxidant activity of solid brem. However, it had no effect on acidity and total phenolic of solid brem.

\subsubsection{Water activity (Aw).}

The addition of the powdered spice formula affects the water activity of the brem product (Table 1). The higher the concentration of the powdered spice formula added, the lower the water activity (Aw) value of the solid brem produced. The decrease in the value of Aw has a relationship with the free water content in the product. The higher the concentration of powdered spices added, the more water molecules are bound to the spice molecules so that the free water contained in the brem product also decreases. This corresponds to Rahmah et al. (2017) that the addition of spices, like red galangal, could reduce the water activity of jerky fish. Hantoro and Mardiono (2018) stated too that commodity spices and their products are hygroscopic and sensitive to water. Low water activity (Morais et al., 2018) has an opportunity to prevent microorganisms proliferate in the products and it can increase the shelf life of products. Products with Aw levels below about 0.70 may well be stable microbiologically and consequently have a longer shelf life.

\subsubsection{Total dissolved solid}

Total dissolved solid is a measure of solutes (both organic and inorganic mineral) present in water (Islam et al., 2016). Based on Table 1, the addition of powdered spices into solid brem did not affect the total dissolved solids of solid brem. Presumably, this is due to a very small change in the value of water activity. However, Table 1 shows that the value of total dissolved solids continued to increase as the concentration of powdered spices was added. The increase in the concentration of the soluble material causes an increase in the total dissolved solids in the material which is followed by a decrease in the value of water activity in the material as the data obtained in this study. The correlation between total dissolved solids and free water (water activity) is strengthened by Andarwulan et al. (2018) which states that the total solid has a negative correlation with water content in the product, meaning, the increase of total solid in the product will be followed the decreasing of water content.

\section{$3.1 .3 \mathrm{pH}$}

During the fermentation of the GRF, the starch breaks down into simple sugars until finally, it forms 
alcohol and organic acids which cause a sweet, alcoholsmelling, and slightly sour taste (Hiovenaguna and Widjanarko, 2017). Table 1 shows that the addition of the concentration of the powdered spice formula affects the $\mathrm{pH}$ value of the product. The $\mathrm{pH}$ value tends to increase as the concentration of powdered spices is added to the solid brem mixture. The increase in $\mathrm{pH}$ value occurs because the spice powder has a higher $\mathrm{pH}$ value than the raw material for making solid brem, namely sticky GRF extract. This is in line with Septiana et al. (2019) that the addition of $1.5-7.5 \%$ spices in honey can increase the $\mathrm{pH}$ of honey significantly from 2.89 become 4 .

\subsubsection{Total phenolic}

Based on statistical analysis, the addition of powdered spice formula does not affect the total phenol brem solid. This insignificant result indicates that the added spice powder concentration has not been able to significantly increase the total phenol of the product. Although the total phenolic in each treatment was not significant statistically, the increase in the total phenolic value in quantity remained and showed that the total phenol increased with the increase in the amount of powdered spices added to the solid brem product. This happened because each type of spice contains phenolic compounds. According to Slowianek and Leszczynska (2016), the total phenolic compounds of nutmeg was 6.3 $\mathrm{mg} \mathrm{GAE} / \mathrm{g}$, ginger was $14.5 \mathrm{mg} \mathrm{GAE} / \mathrm{g}$, clove was 154 mg GAE/g, cinnamon was $155 \mathrm{mg} \mathrm{GAE} / \mathrm{g}$, and turmeric was $42.9 \mathrm{mg} \mathrm{GAE} / \mathrm{g}$. Septiana et al. (2017) have also shown that adding some spices has been shown to increase phenolics in food products.

\subsubsection{Antioxidant activity}

An antioxidant is a compound which in certain levels or amounts could inhibit or reduce the cell damage caused by the oxidation process (Yadav et al., 2016). Table 1 shows that the addition of powdered spice formula affected the antioxidant activity. Based on the orthogonal polynomial test, the more concentration of powdered spice formula added to the solid brem caused the higher antioxidant activity level. This is in line with Sayuti et al. (2018) which showed that traditional drinks with added spices have greater phenolic compounds, free radical scavenging and higher antioxidant activity than traditional drinks without added spices. Edam et al. (2016) reported that powder drinks with the addition of cloves and nutmeg filtrate with the highest $20 \%$ showed the highest antioxidant activity, which was $92.23 \mu \mathrm{g} / \mathrm{mL}$.

This condition is estimated as the effect of phenolic compounds' existence inside of the spice formula, including gingerol, shogaol, alanine, curcumin, and eugenol. Phenolic compounds are responsible for the antioxidant activity of spices and collaborate synergistically with other antioxidant components to prohibit free radicals. The radical scavenging activity is created during the initiation stage of autoxidation (Embuscado, 2015). Adsorbing and neutralizing free radicals, quenching oxygen, and decomposing peroxides became phenolic's redox properties which have a relation with antioxidant activity (Yasin et al., 2017). Although statistically, the total phenol count in this study was not significant, quantitatively the total phenol

Table 2. The physical quality of solid brem with powder spice formula

\begin{tabular}{|c|c|c|}
\hline \multirow{2}{*}{$\begin{array}{c}\text { Concentration of Powdered } \\
\text { spice Formula }(\%)\end{array}$} & \multicolumn{2}{|c|}{ Physical Quality } \\
\hline & Texture $(\mathrm{N})$ & Color $\left(\mathrm{Hue}^{\mathrm{o}}\right)$ \\
\hline 0 & $3.36^{\mathrm{d}}$ & $82.66^{\mathrm{c}}$ \\
\hline 1 & $5.88^{\mathrm{cd}}$ & $89.08^{\mathrm{a}}$ \\
\hline 2 & $6.65^{\mathrm{bc}}$ & $87.00^{\mathrm{ab}}$ \\
\hline 3 & $9.05^{\mathrm{ab}}$ & $83.03^{\mathrm{c}}$ \\
\hline 4 & $9.08^{\mathrm{ab}}$ & $84.68^{\mathrm{bc}}$ \\
\hline 5 & $9.86^{\mathrm{a}}$ & $81.52^{\mathrm{c}}$ \\
\hline HSD & 0.89 & 1.39 \\
\hline
\end{tabular}

HSD: Honestly Significance Difference. Values presented are mean. Values with the same superscripts within the same column are not significantly different at $\mathrm{p} \geq 0.05$.

showed an increase as the concentration of powdered spices was added. The effect that is directly proportional to the increase in total phenol and free radical-blocking capacity indicates a relationship between total phenol and antioxidant activity. Gan et al. (2017) stated that there is a positive correlation between antioxidant activity and total phenol stems from the effectiveness of phenol compounds to eliminate free radicals by donating the hydrogen and forming the stable radical intermediate.

\subsection{Physical quality}

\section{The addition of powdered spices formula} affects the value of texture (hardness) and color $\left(\mathrm{Hue}^{\mathrm{o}}\right)$ as presented in Table 2.

\subsubsection{Texture}

Table 2 show that the texture value of solid brem increases with the increase in the concentration of the powdered spice formula. The values $3,5,6$, and $9 \mathrm{~N}$ in the data above indicate the magnitude of the force exerted by the texture tester (penetrometer). The greater force applied will have an impact on the larger number that appears. This shows the higher the hardness level of a product being tested. An increase in the texture value of the brem product has a relationship with the occurrence of water binding in the solid brem dough. The higher the concentration of powdered spices added, 
the more water molecules are bound to the spice molecule due to its hygroscopic nature (Hantoro and Mardiono, 2018). The impact is that the product becomes harder and the total solids increase. The relationship between water activity, moisture content, and product texture was also explained by Engelen (2018) that the lower the Aw value of a product, the lower the moisture content of the product which resulted in a high value of product hardness or meaning that the product was getting harder.

\subsubsection{Color}

Table 2 shows that the addition of the concentration of powdered spice formula affects the value of ${ }^{\circ} \mathrm{Hue}$ (color degree) of solid brem products. The color value tends to decrease as the concentration of the powdered spice formula in the product increases. The lowest ${ }^{\circ} \mathrm{Hue}$ value shows the color tends to be reddish, while the highest ${ }^{\circ}$ Hue value shows the color tends to be yellowish. The color that tends to be reddish as the

Table 3. The sensory quality (hedonic) of solid brem with powder spice formula

\begin{tabular}{ccccc}
\hline $\begin{array}{c}\text { Concentration of } \\
\text { powdered spice } \\
\text { formulation (\%) }\end{array}$ & \multicolumn{4}{c}{ Sensory Quality (Hedonic) } \\
\cline { 2 - 5 } & Color & Taste & Texture & Mouthfeel \\
\hline 0 & $4.04^{\mathrm{a}}$ & $3.84^{\mathrm{a}}$ & $3.92^{\mathrm{a}}$ & $3.36^{\mathrm{a}}$ \\
1 & $2.64^{\mathrm{c}}$ & $2.4^{\mathrm{b}}$ & $1.96^{\mathrm{b}}$ & $2.48^{\mathrm{bc}}$ \\
2 & $3.4^{\mathrm{b}}$ & $2.68^{\mathrm{b}}$ & $3.08^{\mathrm{b}}$ & $3.24^{\mathrm{ab}}$ \\
3 & $3.28^{\mathrm{b}}$ & $2.56^{\mathrm{b}}$ & $2.8^{\mathrm{b}}$ & $2.44^{\mathrm{c}}$ \\
4 & $2.88^{\mathrm{bc}}$ & $2.48^{\mathrm{b}}$ & $2.64^{\mathrm{b}}$ & $2.64^{\mathrm{abc}}$ \\
5 & $2.64^{\mathrm{c}}$ & $2.52^{\mathrm{b}}$ & $2.92^{\mathrm{b}}$ & $2.72^{\mathrm{abc}}$ \\
\hline
\end{tabular}

Values presented are mean. Values with the same superscripts within the same column are not significantly different at $\mathrm{p} \geq 0.05$.

concentration of the spice formula increases indicates that the spices affect the color change in solid brem products. This opinion is in line with Putri (2018) which states that the yellow spice of turmeric has a coloring effect on food products to which this type of spice is added. Purwitasari et al. (2019) also added that the addition of the concentration of spices in the spiced drink had a significantly different effect on the color of the drink.

The cooking process is also an opportunity for the formation of colors that tend to be brownish-red. This occurs due to a caramelization browning reaction. Caramelization is a nonenzymatic browning reaction because of the heating process which results in the breakdown of sucrose molecules into glucose and fructose followed by the release of water molecules, giving them a brown color (Kocadagli and Gokmen, 2019). The caramelization reaction in solid brem products is caused by solid brem raw material, namely sticky rice juice which contains high sugar. The high sugar content coupled with the presence of heat during the cooking process causes the color of the product to turn brown.

Although there were differences in the ${ }^{\circ} \mathrm{Hue}$ value of each treatment, all data were still in the same color range, namely yellow-red. The yellow-red range is in quadrant $\mathrm{I}\left(\leq 90^{\circ}\right)$ with positive $\mathrm{a}^{*}$ and $\mathrm{b}^{*}$ mean values, to be precise at values 54-90. All ${ }^{\circ} \mathrm{Hue}$ values of each treatment in this study fall into this range so that the main color of the solid brem product in this study is reddish yellow.

\subsection{Sensory quality}

The sensory quality in this study was tested by hedonic test. This test was carried out on four sensory attributes (Table 3), namely color, taste, texture, and melting in the mouth.

\subsubsection{Color}

Color is an important attribute that can be used to attract consumers (Tanner, 2016). A product that has high nutrition, good taste, and good texture, if it does not have attractive color, it will cause the product to be less desirable. Table 3 shows that the test results for the level of liking or hedonic with the average panelist give a solid brem color value ranging from 2.64-4.04 (rather like to like). There was a significant difference in all treatments comparing with control. Moreover, the preference level in color tended to decrease from the addition of $1 \%$ to $5 \%$ powdered spices. This is due to the addition of the concentration of spices in the product. Increasing more spices powder gave strong color in yellow of the product. So that, the panelists prefer to choose sample without additional treatment, which has light yellow.

\subsubsection{Taste}

Table 3 shows that all treatments of adding powdered spice formulas have a significant effect on the control. The test results for the level of liking or hedonic showed the value of solid brem taste ranged from 2.4 to 3.84 (dislike to somewhat like). The highest equivalent value is somewhat favorable to the treatment without the addition of the powdered spice formula. The declining level of palatability as the impact of adding spices on the dough is affected by the original taste from the spices. Ginger gives a pungent and tart taste to the product. This is in line with WilczyNska et al. (2017) that spices in a food product can increase the taste intensity, such as spicy, bitter, resin, and pungent, and decrease the 
intensity of sweet taste. In addition, the slight liking of the products that were not treated with the addition showed that the panelists who carried out the hedonic test were not familiar with the solid brem taste. Therefore, the standards for assessing the taste of this product are low. Taste is the tongue's reaction that happened when the food enters the mouth and it refers to the proximal sense (perception) that influences the final decision of consumers to accept or reject a portion of food that is consumed (Maina, 2018).

\subsubsection{Texture}

The texture is an indicator of sensory properties that influence consumer decisions to like a product. If the texture attribute is bad, it will strongly affect the food acceptability (Maina, 2018). Tabel 3 shows that The test results for the level of liking or hedonic with the average panelist give a solid brem texture value ranging from 1.96-3.92 (dislike to like). The highest value can be found in the treatment without the addition of powdered spice formula and the lowest value in the addition of a $1 \%$ powdered spice formula.

\subsubsection{Melting in the mouth}

Melting in the mouth or ability of the product to crush in the mouth is one of the hallmarks of solid brem products. Solid brem generally has sensory properties that break down easily or dissolve easily in the mouth. There is a cold sensation that is given when it melts in the mouth. Based on the analysis presented in Table 3, the melting value of solid brem ranged from 2.48-3.36 (dislike to somewhat like). Panelists tend to prefer the melting of solid brem products without spices and $2 \%$ spices. For solid brem with $1 \%, 3 \%, 4 \%$, and $5 \%$ spices, panelists tended to dislike the mellow character in the mouth of solid brem products.

\section{Conclusion}

The addition of powdered spices formula affected water activity, $\mathrm{pH}$, physical properties (texture and color), sensory quality (color, taste, texture, and level of melt in the mouth) and does not affect the total solids and total phenolic of brem. The addition of the powdered spice formula by $4 \%$ is recommended to produces solid brem with antioxidant activity of $80.51 \%$; total phenol of $15.71 \mathrm{mg} \mathrm{GAE} / \mathrm{g}$ of ingredients; the total value of dissolved solids was $40.90 \%$ Brix; the value of water activity ( $\mathrm{Aw}$ ) is $0.55 \mathrm{Aw}$; $\mathrm{pH}$ value of 3.44; texture value (physical) of $9.08 \mathrm{~N}$; and the color value (physical) of 84.68 Hue; and the organoleptic quality which the panelists somewhat preferred.

\section{Conflict of interest}

The authors declare no conflict of interest.

\section{References}

Andarwulan, N., Nuraida, L., Adawiyah, D.R., Triana, R.N., Agustin, D. and Gitapratiwi, D. (2018). Effect of soybean varietas on the quality of tofu. Jurnal Mutu Pangan, 5(2), 66-72.

Anisa, F.A., Bintoro, V.P. and Nuwantoro. (2017). Quality of chemical and organoleptic GRF from fermented taro kimpul (Xanthosoma sagittifolium) with various concentration of yeast. Jurnal Aplikasi Teknologi Pangan, 6(1), 43-47. https:// doi.org/10.17728/jatp.207

Afandy, M.K.A. and Widjanarko, S.B. (2018). Optimization of the addition maltodextrin concentration on making solid brem with orange flavour. Jurnal Pangan dan Agroindustri, 6(2), 2332. https://doi.org/10.21776/ub.jpa.2018.006.02.3

Edam, M., Suryanto, E. and Djarkasi, G.S.S. (2016). Formulasi minuman serbuk berbasis lemon cui (Citrus microcarpa) dengan penambahan ekstrak cengkeh (Eugenia carryophyllus) dan ekstrak pala (Myristica fragrans). Chemistry Progress, 9(2), 5054. [In Bahasa Indonesia].

Embuscado, M.E. (2015). Spices and herbs: Natural sources of antioxidants. Journal of Functional Foods, 18, 811-819. https://doi.org/10.1016/ j.jff.2015.03.005

Engelen, A. (2018). Analisis kekerasan, kadar air, warna dan sifat sensori pada pembuatan keripik daun kelor. Journal of Agritech Science, 2(1), 10-15. [In Bahasa Indonesia].

Gan, J., Feng, Y., He, Z., Li, X. and Zhang, H. (2017). Correlations between antioxidant activity and alkaloids and phenols of maca (Lepidium meyenii). Journal of Food Quality, 2017, 3185945. https:// doi.org/10.1155/2017/3185945

Hantoro, M.R. and Mardiono, B. (2018). Eksplorasi desain kemasan berbahan bambu sebagai produk oleh-oleh premium dengan studi kasus produk makanan ukm purnama jati jember. Jurnal Sains dan Seni ITS, 7(1), F68-F71. [In Bahasa Indonesia]. https://doi.org/10.12962/j23373520.v7i1.30041

Hiovenaguna, M.B. and Widjanarko, S.B. (2017). Optimasi proses pembuatan brem padat dengan penambahan sari buah jeruk. Jurnal Pangan dan Agroindustri, 5(3), 6-14. [In Bahasa Indonesia].

Hutching, J.B. (1999). Food Colour and Appearance. $2^{\text {nd }}$ ed. Maryland, USA: Aspen Publisher Inc. https:// doi.org/10.1007/978-1-4615-2373-4

Islam, M.R., Sarkar, M.K.I., Afrin, T., Rahman, S.S., Talukder, R.I., Howladers, B.K. and Khaleque, M.A. 
(2016). A study on total dissolved solids and hardness level of drinking mineral water in Bangladesh. American Journal of Applied Chemistry, 4(5), 164-169. https://doi.org/10.11648/ j.ajac.20160405.11

Ismawati, N., Nurwantoro. and Pramono, Y.B. (2016). The value of $\mathrm{pH}$, total dissolved solids, and sensory properties of yoghurt with addition beet extract (Beta vulgaris L.). Jurnal Aplikasi Teknologi Pangan, 5(3), 89-93.

Khan, M.S., Yusufzai, S.K., Rafatullah, M. and Sarjadi, M.S. (2018). Determination of Total Phenolic Content, Total Flavonoid Content and Antioxidant Activity of Various Organic Crude Extracts of Licuala Spinosa Leaves from Sabah, Malaysia. ASM Science Journal, 11(Special Issue 3), 53-58

Kocadagli, T. and Gokmen, V. (2019). Caramelization in foods: A food quality and safety perspective. Reference Module in Food Science Encyclopedia of Food Chemistry, p. 18-29. Elsevier Online E-Book. https://doi.org/10.1016/B978-0-08-100596-5.216302

Kumar, N. and Goel, N. (2019). Phenolic acids: Natural versatile molecules with promising therapeutic applications. Biotechnology Reports Journal Elsevier, 24, e00370. https://doi.org/10.1016/ j.btre.2019.e00370

Listiana, A. and Herlina. (2015). Characterization of dye herbal drink with composition treatment of red ginger: white turmeric and red ginger: temulawak. AGRITEPA: Jurnal Ilmu dan Teknolgi Pertanian, 2, 171-181. https://doi.org/10.37676/agritepa.v2i1.105

Maina, J.W. (2018). Analysis of the factors that determine food acceptability. The Pharma Innovation Journal, 7(5), 253-257.

Morais, M.P., Caliari, M., Nabeshima, E.H., Batista, J.E.R., Campos, M.R.H. and Junior, M.S.S. (2018). Storage stability of sweet biscuit elaborated with recovered potato starch from effluent of fries' industry. Food Science and Technology Campinas Journal, 38(2), 216-222. https://doi.org/10.1590/ fst.32916

Permata, R.G., Afrianti, L.H. and Sutrisno, E.T. (2015). Kajian perbandingan bahan baku dan bahan pengisi dengan perbandingan sukrosa dan glukosa terhadap karakteristik soft candy salak bongkok (Salacca edulis. Reinw Cv. Bongkok). Bandung: Pasundan University, BSc. Thesis. [In Bahasa Indonesia].

Public Health England (2020). Determination of water activity in food. National Infection Service Food Water and Environmental Microbiology Standard Method. FNES67 Version No. 2. UK: Public Health

\section{England.}

Purwitasari, L., Dwiloka, B. and Setiani, B.E. (2019). The changes on the hedonic quality at the first and the second brewing spiced drinks. Jurnal Teknologi Pangan, 3(2), 269-272.

Putri, M.K.R. (2018). Pengaruh berbagai formulasi bumbu rempah alami terhadap waktu simpan opor ayam. Bandar Lampung: Lampung University, BSc. Thesis. [In Bahasa Indonesia].

Rahmadani, S., Sa'diah, S. and Wardatun, S. (2015). Optimasi ekstraksi jahe merah (Zingiber officinale roscoe) dengan metode maserasi. Jurnal Online Mahasiswa, 1(1), 1-10. [In Bahasa Indonesia].

Sayuti, N.A., Dewi, I.K. and Rusita, Y.D. (2018). Pengembangan formula wedang secang sebagai minuman kemasan rendah kalori. Jurnal Terpadu Ilmu Kesehatan, 7(1), 87-95. [In Bahasa Indonesia]. https://doi.org/10.37341/interest.v7i1.77

Septiana, A.T., Samsi, M. and Mustaufik M. (2017). Pengaruh penambahan rempah dan bentuk minuman terhadap aktivitas antioksidan berbagai minuman tradisional indonesia. AGRITECH Journal, 37(1), 714. [In Bahasa Indonesia]. https://doi.org/10.22146/ agritech. 17001

Septiana, A.T., Handayani, I. and Winarsi, H. (2019). Antioxidant activity and physicochemical properties of Curcuma zanthorrhiza Roxb added with extract of ginger (Zingiber officinale Rosc). Jurnal Aplikasi Teknologi Pangan, 8(4), 155-160. https:// doi.org/10.17728/jatp.4849

Slowianek, M. and Leszczynska, J. (2016). Antioxidant properties of selected culinary spices. Herba Polonica Journal, 62(1), 29-41. https:// doi.org/10.1515/hepo-2016-0003

Tanner, D. (2016). Impacts of storage on food quality. Reference Module in Food Science, p. 1-4. Elsevier Online E-Book. https://doi.org/10.1016/B978-0-08100596-5.03479-X

Wijewardhana, U., Gunathilaka, S. and Navaratul, S. (2019). Determination of total phenolic content, radical scavenging activity and total antioxidant capacity of cinnamon bark, black cumin seeds, garlic. International Research Journal of Advanced Engineering and Sciences, 4 (2):55-57.

WilczyNska, A., Newerli-Guz, J. and Szweda, P. (2017). Influence of the Addition of Selected Spices on Sensory Quality and Biological Activity of Honey. Journal of Food Quality, 2017, 6963904. https:// doi.org/10.1155/2017/6963904

Yadav, A., Kumari, R., Yadav, A., Mishra, J.P., Srivatya, S. and Prabha, S. (2016). Antioxidants and its functions in human body - a review. Research in 
Environment and Life Science, 9(11), 1328-1331.

Yashin, A., Yashin, Y., Xia, X. and Nemzer, B. (2017). Antioxidant Activity of Spices and Their Impact on Human Health. Antioxidants Journal MDPI, 6 (3), 70. https://doi.org/10.3390/antiox6030070

Yasin, H.K. (2013). Studi pembuatan minuman tradisional Bima "Mina Sarua" instan. Makassar: Hasanuddin University, BSc. Thesis. [In Bahasa Indonesia]. 